\title{
EXCHANGE RATE LINKAGES BETWEEN THE ASEAN CURRENCIES, THE US DOLLAR AND THE CHINESE RMB
}

\author{
Guglielmo Maria Caporale, Brunel University London \\ Luis A. Gil-Alana, University of Navarra \\ Kefei You, University of Greenwich
}

June 2016

\begin{abstract}
This paper investigates whether the RMB is in the process of replacing the US dollar as the anchor currency in nine ASEAN countries, and also the linkages between the ASEAN currencies and a regional currency unit. A long-memory (fractional integration) model allowing for endogenously determined structural breaks is estimated for these purposes (Gil-Alana, 2008). The results suggest that the ASEAN currencies are much more interlinked than previously thought, whether or not breaks are taken into account, which provides support for a regional currency index as an anchor. Moreover, incorporating a break shows that the linkages between these currencies and the RMB and the US dollar respectively are equally important, and in fact in recent years the former have become stronger than the latter. Therefore including the RMB in the regional index should be considered.
\end{abstract}

Keywords: ASEAN currencies, Chinese RMB, US dollar peg, fractional integration, breaks

JEL classification: F31, C22

Corresponding author: Professor Guglielmo Maria Caporale, Department of Economics and Finance, Brunel University London, UB8 3PH, UK. Tel.: +44 (0)1895 266713. Fax: +44 (0)1895 269770. Email: Guglielmo.Maria.Caporale@brunel.ac.uk

The second-named author gratefully acknowledges financial support from the Ministerio de Economía y Competitividad (ECO2014-55236). 


\section{Introduction}

Since the financial crisis of the late 1990s, the East Asian economies have taken various steps towards greater economic integration within the region. Regional financial forums, such as the Association of Southeast Asian National Plus Three $(\text { ASEAN }+3)^{1}$ and the Executive Meeting of East Asia-Pacific Central Banks (EMEAP), have been actively promoting deeper market-led integration and policy-induced cooperation. Several regional initiatives, including the Chiang Mai initiative (CMI) in 2002, the Asian Bond Market Initiative (ABMI) in 2003, and the new ABMI Roadmap in 2008, were put in place to strengthen regional cooperation and integration. Further, the number of Free Trade Agreements (FTAs) in Asia has been rising steadily, reaching 154 and 61 respectively at the bilateral and multilateral level in 2015 (ADB, 2015).

As a result, there has been an increase in trade and capital flows within the region. ${ }^{2}$ In particular, ASEAN financial integration has made significant progress: direct investment has risen, cross-border banking linkages have deepened, and foreign participation in ASEAN capital markets has increased (Almekinders et al., 2015). At the same time, these economies compete with each other at the global level for trade, foreign direct investment (FDI) and financial resources; this is a consequence of the similar export- and investment-led economic growth model shared by many Asian countries.

Regardless of whether the increasing interdependence in East Asia is due to economic integration or competition, exchange rate stability remains of paramount importance. The currencies of the ASEAN economies were strongly linked to the US

\footnotetext{
${ }^{1}$ ASEAN +3 includes the 10 members of the Association of Southeast Asian Nations (Brunei Darussalam, Cambodia, Indonesia, Lao People's Democratic Republic, Malaysia, Myanmar, the Philippines, Singapore, Thailand, and Vietnam) plus the People's Republic of China, Japan, and South Korea.

${ }^{2}$ Whilst the growth rate of global trade has declined in recent years, Asia's intra-regional trade share has stabilised since the early 2000s at around 55\%, the strongest trade links being found in Southeast Asia (ADB 2015).
} 
dollar in the past. Following the financial crisis of the late 1990s, the reintroduction of a US dollar peg in Asia in the period 1999-2003 was described by some researchers as the “dollar standard” (e.g., McKinnon and Schnabl, 2004). There is ample empirical evidence suggesting that, despite the more flexible exchange rate regimes subsequently adopted by some Asian countries, the US dollar was still the de facto anchor currency for many of them (e.g., Benassy-Quere et al., 2006). As explained by Volz (2014), there are several reasons for the dominant role of the US dollar in the East Asian region, such as aiming for macroeconomic stability, a higher degree of intra-regional exchange rate stability, and higher competitiveness of the export sector.

However, the choice of the anchoring currency has become less obvious for the ASEAN countries since China started acquiring a more global role. On the one hand, the trade linkages between ASEAN and China have become much stronger. For instance, by 2013, China had become their largest individual trading partner (14\% share of ASEAN trade), while the US was only the fourth largest (8.2\% share) (Salidjanova et al., 2015). On the other hand, the ASEAN countries compete with China for exports to the Western countries and for foreign direct investment. In recent years China has started to lose its competitive edge owing to rising real wages and a declining labour supply, and therefore the exchange rate for the currencies of the ASEAN countries visà-vis the Renminbi (RMB) has become increasingly important. In the same period the Chinese government has embarked on an ambitious and successful scheme to further the internationalisation of the RMB, with an increasing impact on the other Asian currencies (e.g., Ho et al., 2005; Colavecchio and Funke, 2009). Pontines and Siregar (2012) found that there is a greater degree of aversion in the East Asian countries to their currencies appreciating vis-a-vis the Chinese RMB as opposed to the US dollar which results from the concern about potential competitiveness losses vis-à-vis China. 
Given the gradual decline of the US dollar and the simultaneous rise of the RMB as the dominant currency in the foreign exchange markets, as well as the increasingly strong economic linkages between the ASEAN region and China, one would expect the currencies of these countries to follow more closely the fluctuations of the RMB. Indeed, recent studies have found that the latter has acquired an increasingly important role in driving the region's currencies (e.g., Chen et al., 2010; Henning, 2012; Fratzscher and Mehl, 2014), or have even suggested that a RMB bloc has already been formed (e.g., Subramanian and Kessler, 2012).

The present paper investigates exchange rate linkages between the currencies of the ASEAN region and the RMB and the US dollar respectively. More specifically, it applies a long-range dependence approach based on the concept of fractional integration to analyse the relationship between the ASEAN real exchange rates vis-à-vis the RMB and the US dollar respectively. Given the fact that the Chinese exchange rate regime has undergone several changes over the years, the possibility of structural breaks in the series is taken into account. In addition to external anchors (the RMB and the US dollar) intra-regional pegs are also investigated.

The existing literature has employed various methods to examine the issue of the anchoring currency in Asia. Following Franken and Wei (1992), both Ogawa and Shimitzu (2005) and Kawai (2007) regressed special-drawing-right (SDR) exchange rate returns of the domestic currency on the returns of the US dollar, yen, and euro visa-vis the SDR, and showed the resilience of the US dollar peg in the East Asian countries up to the mid-2000s. A similar conclusion was reached by Hernandez and Montiel (2003) by employing the relative volatilities of exchange market pressure indices. ${ }^{3}$ On the other hand, Girardin (2011) employed an approach combining two

\footnotetext{
3 This method is also employed by Calvo and Reinhart (2002) and Levy-Yeyati and Sturzeneger (2003, 2005). It compares exchange rate variability to foreign exchange reserve variability. Specifically, the
} 
methods (as in Frankel and Wei, 2008) and reported that, since the late 1990s, the majority of the East Asian currencies have moved away from the US dollar and towards basket pegs with a dominant role for an Asian Currency Unit. Another set of papers analyse the real exchange rate of the Asian currencies, in the context of the Purchasing Power Parity (PPP) hypothesis, employing classical cointegration models (e.g., Wilson and Choy, 2007; Sun and Simons, 2011, Ogawa and Kawasaki, 2008; Mishra and Sharma, 2010).

The aforementioned studies suffer from several limitations. First, the classical I(0) vs. I(1) dichotomy cannot capture the dynamic behaviour of highly persistent exchange rate series with long-lived deviations from equilibrium and very slow mean reversion (see Gil-Alana, 2000; Caporale and Gil-Alana, 2004). Therefore, in this study we allow the degree of integration $d$ to be fractional to model long memory in the real exchange rates of the ASEAN economies. Specifically, if the fractional differencing parameter d for their real exchange rates vis-à-vis a possible anchor is smaller than 1 , then mean reversion occurs and there is evidence that ASEAN exchange rates are linked in the long run to that currency; since the parameter $\mathrm{d}$ indicates the speed of adjustment, the smaller the value of $d$, the faster the process of convergence towards equilibrium is. On the other hand, if the estimated value of $d$ is equal to or higher than 1 , there is no evidence of mean reversion. Such methods, despite being used to analyse various real exchange rate series, have only been applied in very few previous studies in the case of the ASEAN currencies (see the discussion in the next section).

Second, given the increasing role of China in the region, it is surprising that hardly any studies have examined whether the RMB is replacing the US dollar as the anchor currency, especially since the exchange rate policy reforms adopted in China in reserve, is employed to capture shocks in the demand for the currency. 
2005. ${ }^{4}$ In the present paper we consider the PPP-based real exchange rate of the ASEAN currencies vis-a-vis not only the US dollar but also the Chinese RMB to examine whether and to what extent they are now following the latter rather than the former. In addition, we are also interested in establishing whether they are linked instead to an ASEAN regional currency unit, since the issue of a regional currency in Asia has been widely discussed recently; for instance Girardin (2011) found evidence for basket pegs in Asia with a predominant role for an Asian Currency Unit.

Third, parameter or regime shifts are known to affect many currencies (Frankel and Xie, 2010). Hence, it is important to allow for the possibility of structural breaks in the time period under investigation. For this purpose, we use the method proposed by Gil-Alana (2008) that allows for structural breaks within a fractional integration framework, with the number of breaks and the break dates being determined endogenously.

Our analysis provides valuable information to policy makers on the exchange rates linkages of the ASEAN currencies vis-à-vis the RMB and the US dollar and on which of the two would be more suitable as a de facto anchoring currency (basket). The paper is structured as follows: Section 2 discusses the long-range dependence approach as well as structural breaks in a fractional integration framework. Section 3 presents the data and the main empirical results, while Section 4 offers some concluding remarks and draws some policy implications.

\footnotetext{
${ }^{4}$ The previously mentioned studies that evaluate the importance of the RMB in the region follow the regression-based approaches proposed by Frankel and Wei (1992, 2008) (e.g., Chen et al., 2009; Henning, 2012; Subramanian and Kessler, 2012) and hence have the limitation highlighted above. Although Fratzscher and Mehl (2011) employ a factor model and Granger causality analysis, they again do not deal with the long memory issue of the exchange rates.
} 


\section{Methodology}

The approach taken in this study is based on the concept of fractional integration, which allows the differencing parameter $\mathrm{d}$ required to make a series stationary $\mathrm{I}(0)$ to be any real value including fractions. Specifically, a time series is defined to be I(d) if it can be represented as

$$
(1-L)^{d} x_{t}=u_{t}, t=1,2, \ldots,
$$

with $\mathrm{x}_{\mathrm{t}}=0, \mathrm{t} \leq 0$, where $\mathrm{u}_{\mathrm{t}}$ is an $\mathrm{I}(0)$ process, defined as a covariance stationary process with a spectral density function that is positive and finite, and L is the backward shift operator $\left(\mathrm{L} \mathrm{x}_{\mathrm{t}}=\mathrm{x}_{\mathrm{t}-1}\right)$. If $\mathrm{d}$ is not an integer, the series $\mathrm{x}_{\mathrm{t}}$ requires fractional differencing in order to obtain a stationary (possibly) ARMA series. ARIMA(p,d,q) models in which d is a positive integer are special cases of the general process in (1). If $d>0$ in (1), $x_{t}$ is said to exhibit long memory because of the strong association between observations far apart in time.

Evidence of long memory or fractional integration may be due to aggregation: the aggregation of independent weakly dependent series can produce a strongly dependent series. Robinson (1978) and Granger (1980) showed that fractional integration can arise as a result of aggregating heterogeneous autoregressive (AR) processes. This issue was further analysed by Taqqu et al. (1997), Chambers (1998), Parke (1999), etc. ${ }^{5}$

In this study we use both parametric and semi-parametric techniques. The former include a Whittle approach in the frequency domain (Dahlhaus, 1989) and the Robinson (1994) test; the latter has several advantages over other approaches: first, it is based on the Lagrange Multiplier (LM) principle, and therefore it is a test of the null hypothesis that $\mathrm{d}$ can be any real value not requiring a consistent estimate of $\mathrm{d}$; second,

\footnotetext{
${ }^{5}$ See also Souza (2005) and Hassler (2011) for an explanation of fractional integration in terms of temporal aggregation.
} 
it is valid even in non-stationary contexts (i.e., $\mathrm{d} \geq 0.5$ ) and hence does not require prior differencing, unlike all other procedures (Sowell, 1992, Beran, 1995; Robinson, 1995; etc.); third, it is the most efficient in the Pitman sense against local departures from the null, with the limit distribution being a standard normal. Other, more standard parametric methods (Sowell, 1992, Beran, 1995) produced essentially the same results. The semi-parametric approach is a "local" Whittle method initially developed by Robinson (1995) and later extended by Phillips and Shimotsu (2004, 2005), Abadir et al. (2007) and others.

Fractional integration has been widely applied to the exchange rates of developed countries (e.g., Caporale and Gil-Alana, 2004). More recently, it has also been employed in the case of the Latin America and African countries (e.g., Caporale and Gil-Alana, 2010, 2013, 2015 and Balparda et al., 2016 ). However, very few papers have applied long-memory or fractional integration methods to the exchange rates of the South East Asia currencies. Holmes (2002) employed the semi-parametric procedure of Geweke and Porter-Hudak (1983) for the currencies of four ASEAN countries (Indonesia, Philippine, Singapore, and Thailand) using quarterly data over the period 1973-2001. Soofi et al. (2006) adopted the plug-in and the Whittle maximum-likelihood methods to analyse the daily exchange rates of twelve Asian economies from January 1993 to September 2005; five ASEAN countries (Indonesia, Malaysia, Philippine, Singapore, and Thailand) were included in the sample. Floros (2008) used a fractionally integrated autoregressive moving average (ARFIMA) framework to examine the daily exchange rates of thirty-four countries, including three ASEAN ones (Malaysia, Philippines and Singapore), over the period from April 1991 to April 2006. All these three papers only consider the exchange rates vis-à-vis the US dollar, and only Soofi et al. (2006) allow for a (single) structural break in the data. 


\section{Empirical results}

\section{Data Description}

The series analysed are the monthly real exchange rates of nine ASEAN countries (Brunei Darussalam, Cambodia, Indonesia, Lao, Malaysia, Philippine, Singapore, Thailand, and Vietnam) covering the period 1995m1-2014m12. There are three sets of exchange rates. The first includes those vis-à-vis the US dollar, obtained by adjusting the nominal exchange rates of the ASEAN currencies vis-a-vis the US dollar by the relative CPI between the ASEAN countries and the US. The second are calculated in a similar way, but replacing the US dollar with the RMB and the US CPI with China's CPI. The third set are obtained by first constructing a real regional index as a weighted average of the real exchange rate indices of the nine ASEAN currencies (vis-a-vis the US dollar), where the weights are given by real GDP, and then adjusting each ASEAN real exchange rate with the regional index. The base year is the same in all cases (2010=100). The data (nominal exchange rates, CPIs, and real GDP) are taken from the International Financial Statistics of the International Monetary Fund.

\section{Results}

First we estimate the fractional differencing parameter $d$ in the following model,

$$
y_{t}=\alpha+\beta t+x_{t} ; \quad(1-L)^{d} x_{t}=u_{t}, \quad t=1,2, \ldots
$$

where $\mathrm{y}_{\mathrm{t}}$ is the observed time series, $\alpha$ and $\beta$ are the deterministic terms (an intercept and a linear time trend, respectively), $\mathrm{x}_{t}$ is assumed to be $\mathrm{I}(\mathrm{d})$, and $\mathrm{u}_{\mathrm{t}}$ is $\mathrm{I}(0)$ and specified as a white noise and an autocorrelated process in turn. We consider the three cases of a) no regressors (i.e., $\alpha=\beta=0$ a priori in (3)), an intercept (i.e., $\alpha$ unknown and $\beta=0$ a priori), and an intercept with a linear time trend (i.e., $\alpha$ and $\beta$ unknown), reporting the (Whittle) estimates of $d$ along with their corresponding 95\% confidence 
intervals of the non-rejection values of d with the tests of Robinson (1994). Table 1 shows the results based on white noise errors and Table 2 those with autocorrelated disturbances.

In Table 3 we display the estimates of $d$ using the semiparametric approach of Robinson (1995), which is basically a local 'Whittle estimator' in the frequency domain using a band of frequencies that degenerates to zero. The estimator is implicitly defined by:

$$
\begin{gathered}
\hat{d}=\arg \min _{d}\left(\log \overline{C(d)}-2 d \frac{1}{m} \sum_{s=1}^{m} \log \lambda_{s}\right), \\
\overline{C(d)}=\frac{1}{m} \sum_{s=1}^{m} I\left(\lambda_{s}\right) \lambda_{s}^{2 d}, \quad \lambda_{s}=\frac{2 \pi s}{T}, \quad \frac{m}{T} \rightarrow 0,
\end{gathered}
$$

where $\mathrm{I}\left(\lambda_{\mathrm{s}}\right)$ is the periodogram of the raw time series, $\mathrm{x}_{\mathrm{t}}$, given by:

$$
I\left(\lambda_{s}\right)=\frac{1}{2 \pi T}\left|\sum_{t=1}^{T} x_{t} e^{i \lambda_{s} t}\right|^{2},
$$

and $d \in(-0.5,0.5)$.

\section{[Insert Table 1 about here]}

We mainly focus on the case with an intercept (since the coefficients were not found to be statistically significant in the model with a linear time trend). When applying the parametric method under the assumption of white noise disturbances (in Table 1) the estimated value of $d$ is higher than 1 in all cases for the real exchange rates constructed using the real regional index, and the unit root null hypothesis (i.e., $d=1$ ) cannot be rejected in the cases of Cambodia, Indonesia, Lao, Malaysia, Phillippines and Thailand, while it is rejected in favour of higher orders of integration ( $d>1$ and thus rejecting the market efficiency hypothesis) in the cases of Brunei, Singapore and Vietnam. When the exchange rates vis-à-vis the US dollar are considered, those for 
Indonesia, Malaysia and Vietnam turn out to be the only ones offering evidence of a random walk; finally, in the case of the exchange rates vis-à-vis the $\mathrm{RMB}$, there is evidence of a unit root for those of Brunei, Cambodia, Indonesia, Malaysia and Singapore, whilst for the remaining series the estimated value of $\mathrm{d}$ is found to be statistically significant and higher than 1 .

\section{[Insert Table 2 about here]}

When still using a parametric method, but assuming that the errors are autocorrelated and following the exponential approach of Bloomfield (1973), ${ }^{6}$ the estimated values of $d$ are smaller than in the case of white noise $u_{t}$, being either within the unit root interval or smaller than 1 . The latter implies that shocks have only transitory effects and mean reversion occurs; this holds in four cases when using the regional index to construct the real exchange rates (Indonesia, Laos, Malaysia and Philippines), two when considering the rates vis-à-vis the US dollar (Indonesia and Thailand), and one (Indonesia) for the exchange rates vis-à-vis the RMB.

\section{[Insert Table 3 about here]}

Table 3 reports the results for the semi-parametric "local" Whittle method of Robinson (1995) for selected bandwidth parameters $(m=11.12 . \ldots, 19) .^{7}$ The cases in bold are those with a unit root (i.e., $d=1$ ). The results are consistent with the ones based on parametric methods. Evidence of mean reversion $(\mathrm{d}<1)$ is obtained for the exchange rates vis-à-vis the regional index in the cases of Brunei, Indonesia, Lao, Malaysia, Singapore and Thailand; for the rates vis-à-vis the US dollar most values are within the unit root circle or above, and evidence of mean reversion is only found for Indonesia and to some extent for Thailand. Finally, in the case of the rates vis-à-vis sthe

\footnotetext{
6 This is a way of approximating ARMA processes using a model based only on the he spectral density function but performimg extremely well in the context of fractional integration (see, e.g. Gil-Alana, 2004).

${ }^{7}$ The choice of the bandwidth shows the trade-off between bias and variance: the asymptotic variance and the bias are decreasing and increasing respectively with $\mathrm{m}$.
} 
RMB mean reversion occurs for the currencies of Indonesia and to some extent for those of Laos and Thailand.

It is noteworthy that mean reversion is mostly found when using the parametric model with autocorrelated disturbances (Table 2) and the semiparametric model (Table 3). In both cases, the strongest evidence is obtained for the exchange rates of the ASEAN currencies vis-a-vis the regional index, the evidence being much weaker vis-àvis the US dollar, since mean reversion is only found for the currencies of Indonesia and Thailand. This is in contrast to earlier studies suggesting that the US dollar is the dominant anchoring currency for the East Asian countries (e.g., McKinnon and Schnabel, 2004; Benassy-Qurer et al., 2006; Kawai and Pontines, 2014). More interestingly, only for the currency of one country (Indonesia) there is evidence of mean reversion when considering the exchange rates vis-à-vis the RMB, although there is some evidence also in the case of Laos and Thailand when using the semiparametric model. This is in contrast to other studies finding a dominant role of the RMB in the region (e.g., Chen et al. (2010), Henning (2012) and Fratzscher and Mehl (2014)) or the formation of a RMB bloc (Subramanian and Kessler, 2012). Therefore, our results suggest that the ASEAN currencies are more strongly linked to the regional index than either to the US dollar or the RMB, which is in line with the conclusions of Girardin (2011), who found that a majority of East Asian countries moved away from the dollar peg and started targeting an Asian Currency Unit in the late 1990s.

Finally, the fact that the estimated values of $d$ are very similar in the case of autocorrelated disturbances (in Table 2) and with the semiparametric approach (in Table 3) suggests that the errors may be weakly autocorrelated, perhaps owing to the existence of structural breaks in the data. This is an important feature of many macroeconomic series, particularly so in the case of ASEAN economies. It is now well known that 
structural breaks and fractional integration are tightly linked (Diebold and Inoue, 2001; Granger and Hyung, 2004; etc.). Therefore next we examine the possibility of structural breaks, first imposing a single break and then carrying out the Bai and Perron (1998, 2003) tests for detecting multiple breaks endogenously. The results for the case of a single break are reported in Table 4. The most common break date is 1998M01, followed by others in 2007 and 2008.

\section{[Insert Table 4 about here]}

Table 5 reports the results when allowing for multiple breaks, again the most common dates being 1998M1 and others in 2007 and 2008, corresponding to the Asian financial crisis of the late 1990s and the 2008 global financial crisis.

\section{[Insert Table 5 about here]}

Tables 6 - 8 present the results obtained when allowing for a different degree of fractional integration in each of the subsamples using the Bai and Perron $(1998,2003)$ tests. In this case no evidence of mean reversion is found for any series, except in the cases of the sub-sample $1995 \mathrm{~m} 01-1997 \mathrm{~m} 12$ for the exchange rates of Indonesia, Malaysia and Thailand (see Table 6).

\section{[Insert Tables 6 - 8 about here]}

This lack of mean reversion in the subsamples can be due to the large number of breaks detected with Bai and Perron (2003) method and the corresponding small number of observations for the subsamples. For this reason we also employ Gil-Alana's (2008) approach only allowing for a single break in the series. This method estimates the fractional differencing parameter for each subsample and allows the break date to be determined endogenously. The results are presented in Tables 9 and 10 for the cases of white noise and autocorrelated (Bloomfield) disturbances respectively. Reassuringly, 
the break dates are found to be the same as when using the Bai and Perron's (2003) method (except in a few cases when they differ by a single month). ${ }^{8}$

\section{[Insert Tables 9 and 10 about here]}

When assuming white noise errors (Table 9), only in Malaysia there is a significant difference between the first and the second subsamples, and no evidence of mean reversion is found, except in the first subsample in Vietnam. By contrast, in the case of autocorrelated disturbances (Table 10), some interesting results emerge. First, the estimated values of $d$ are either unity or smaller than 1 . Second, consistently with the previous findings, the strongest evidence of mean reversion is found for the exchange rates of the ASEAN currencies vis-à-vis the regional index: this holds for all of them except Brunei, in two cases (Malaysia and Thailand) in both sub-periods, in three (Lao, Philippines and Vietnam) before the break and in three (Cambodia, Indonesia and Singapore) after the break. In the case of Lao and Thailand, there are significant differences between the first and the second subsamples, again confirming the importance of allowing for breaks. By comparison, in the case of the ASEAN rates vis-à-vis the USD, only for six currencies (Brunei, Indonesia, Malaysia, Philippines, Singapore, Thailand) we find $d<1$ in either the first or the second sub-period. Third, for six of the ASEAN currency rates vis-à-vis the Chinese RMB (Brunei, Cambodia, Indonesia, Malaysia, Philippines and Singapore), the estimated value of $d$ is smaller than 1, which implies mean reversion, in five of them (Indonesia is the exception) in the second sub-sample, in contrast to the case of the rates vis-à-vis the US dollar, when only four (Brunei, Malaysia, Philippines and Singapore) out of six exhibit mean reversion; this difference only becomes apparent when allowing for a single break. Fourth, when comparing the results for the ASEAN currency rates vis-à-vis the regional index and the

\footnotetext{
8 The only differences compared to Table 4 are for the exchange rates of Malaysia vis-à-vis the regional index (2003M07); the Philippines vis-a-vis the US dollar (2007M10); Vietnam vis-à-vis the regional index (2009M11) and the RMB (2008M08); Singapore vis-a-vis the US dollar (2010M10).
} 
Chinese RMB respectively one can notice that, although there are clearly more cases of mean reversion for the former than the latter, in the second sub-sample the number of cases (five) is the same.

To sum up, in contrast to previous studies that suggest a dominant role for the US dollar in the South East Asian region, our findings suggest that the strongest linkages are those between the ASEAN currencies and their regional index, regardless of whether or not one allows for breaks. Moreover, evidence of strong linkages between the ASEAN currencies and the Chinese RMB is also obtained when one allows for a single break: although weaker than with the regional index, they are as strong as those with the US dollar and even stronger in the more recent period, when the Chinese RMB appears to have been gaining a similar status to the US dollar in the South East Asian region.

\section{Conclusions}

Given the increasingly important role of the Chinese RMB as an international currency and the strengthening trade and investment relationships between China and the other South East Asian countries, this paper has investigated whether the RMB is in the process of replacing the US dollar as the anchor currency in nine ASEAN countries. Further, since the issue of “Asian Currency Unit” has been widely discussed, it has also examined the linkages between the ASEAN currencies and a regional currency unit. A long memory (or fractional integration) model allowing for endogenously determined structural breaks is estimated for these purposes (Gil-Alana, 2008). The results suggest that the ASEAN currencies are much more interlinked than previously thought, whether or not breaks are taken into account. Moreover, incorporating a break shows that the linkages between these currencies and the RMB and the US dollar respectively are 
equally important, and in fact in recent years the former have become stronger than the latter. $^{10}$

On the whole our study suggests that a suitable anchor for the ASEAN currencies is regional more than external and also highlights the increasingly important role of the Chinese RMB, in competition with the US dollar, as the main external anchoring currency for the region. This has important policy implications. First, the greater influence of the RMB in the region has been associated with reforms of the exchange rate regime allowing wider fluctuations of the currency. If this influence and the internationalisation of the RMB are to be enhanced both at the regional and the global level, then the reform process should continue, granting more flexibility to the currency and eventually moving to a full float. Second, concerning the issue of the composition of the Asian Currency Unit (see Kenen and Meade, 2008), the observed tighter inter-regional linkages between the ASEAN currencies compared to those with the US dollar provide support for a regional currency index. Although our findings do not imply that the RMB should necessarily become the anchor for the ASEAN region (see also Park, 2008), its observed increasingly influence suggests (in contrast to Kenen and Meade, 2008) that perhaps a regional index including it, or even an RMB-centred one reflecting its growing international role, would be more suitable (see also Mundell, 2003 and Ma and McCauley, 2010)

\footnotetext{
${ }^{10}$ The differences between the individual ASEAN exchange rates emerging from Table 9 and 10 could reflect different fiscal balances, economic growth rates, relative competitive positions and monetary policy stance; for example, You and Sarantis (2011, 2012a, 2012b) incorporate a range of economic fundamentals into alternative exchange rate models to determine the value of the yuan. However, these issues are beyond the scope of the present study.
} 


\section{References}

Abadir, K.M., Distaso, W. and Giraitis, L. (2007) Nonstationarity-extended local Whittle estimation, Journal of Econometrics 141, 1353-1384.

Almekinders, G., Fukuda, S., Mourmouras, A., Zhou, J. and Zhou, Y. S. (2015) ASEAN Financial Integration, IMF Staff Paper WP/15/34.

Asian Development Bank (2015) How Can Special Economic Zones Catalyze Economic Development? Asian Economic Integration Report 2015.

Bai J., P. Perron (1998). Estimating and testing linear models with multiple structural changes. Econometrica, vol. 66.

Bai J., P. Perron (2003). Computation and analysis of multiple structural change models.Journal of Applied Econometrics, vol. 18.

Bénassy-Quéré, A., Coeuré B. and Mignon, V. 2006. On the Identification of De Facto Currency Pegs. Journal of the Japanese and International Economies, 20(1), 112-27.

Beran, J., 1995, Maximum likelihood estimation of the differencing parameter for invertible short and long memory ARIMA models, Journal of the Royal Statistical Society, Series B, 57, 659-672.

Calvo, G. A., and C. M. Reinhart. 2002. Fear of Floating. Quarterly Journal of Economics 107(2): 379-408.

Caporale, G.M. and L.A. Gil-Alana (2004), "Fractional cointegration and real exchange rates”, Review of Financial Economics, 13, 4, 327-340.

Caporale, G.M. and L.A. Gil-Alana (2010), "Real exchange rates in Latin America: the PPP hypothesis and fractional integration”, Journal of Economic Development, 35, 2, 121.

Caporale, G.M. and L.A. Gil-Alana (2013), "Testing the PPP hypothesis in the SubSaharan countries”, Journal of African Studies and Development, 5, 4, 57-63.

Caporale, G.M. and L.A. Gil-Alana (2015), "Testing PPP for the South African rand/US dollar real exchange rate at different data frequencies", 27, 2, 161-170, African Development Review.

Balparda, B., Caporale, G.M., Carcel, H. and L.A. Gil-Alana (2016), “Exchange rate dynamics and monetary unions in Africa: a fractional integration and cointegration analysis”, forthcoming, African Journal of Business Management.

Chambers, M., 1998, Long memory and aggregation in macroeconomic time series.International Economic Review 39, 1053-1072. 
Chen H., W. Peng and C. Shu (2010), The Potential of the Renminbi as an International Currency; in Currency Internationalization, Global Experiences and Implications for the Renminbi, pp 115-138, Springer-Link.

Colavecchio, R., and Funke, M. (2009). Volatility dependence across Asia-Pacific onshore and off-shore U.S. dollar future markets, Journal of Asian Economics 20, 2, 174196.

Dahlhaus, R., 1989, Efficient parameter estimation for self-similar processes, Annals of Statistics 17, 1749-1766.

Diebold F.X. and A. Inoue, 2001, Long memory and regime switching, Journal of Econometrics 105, 131-159.

Floros, C. (2008), Long Memory in Exchange Rates: International Evidence, International Journal of Business and Finance Research, 2 (1)

Frankel J. A., and Wei S. J. (1992) Yen Block or Dollar Block? Exchange Rate Policies in the East-Asian Economies. In Macroeconomic Linkages, edited by T. Ito, and A. Krueger. Chicago, IL: University of Chicago Press.

Frankel J. A., and Wei S. J. (2008) 2008. Estimating De Facto Exchange Rate Regimes: Synthesis of the Techniques for Inferring Flexibility and Basket Weights. IMF Staff Papers 55(3): 384-416.

Frankel J. A., and Xie D. (2010) Estimation of De Facto Flexibility Parameters and Basket Weights in Evolving Exchange Rate Regimes. American Economic Review 100(2): 568-572.

Fratzscher, M., and A. Mehl. 2014. China's Dominance Hypothesis and the Emergence of a Tri-Polar Global Currency System. The Economic Journal 124, 581, 1343-1370.

Geweke, J. and Porter-Hudak, S. (1983) The estimation and application of long memory time series models, Journal of Time Series Analysis 4, 221-238.

Gil-Alana, L. A. (2000) "Mean reversion in the real exchange rates”, Economics Letters, vol. 69, p. 285-288.

Gil-Alana, L. A. (2004) The use of the Bloomfield (1973) model as an approximation to ARMA processes in the context of fractional integration, Mathematical and Computer Modelling, 39: 429-436.

Gil-Alana, L.A. 2008. Fractional integration and structural breaks at unknown periods of time. Journal of Time Series Analysis, 29, 163-185.

Girardin, E. 2011. A De Facto Asian-Currency Unit Bloc in East Asia: It Has Been There but We Did Not Look for It. ADBI Working Paper Series 11/262. Tokyo: Asian Development Bank Institute. 
Granger, C.W.J., (1980), Long memory relationships and the aggregation of dynamic models, Journal of Econometrics 14, 227-238.

Granger, C.W.J. and N. Hyung, 2004, Occasional structural breaks and long memory with an application to the S\&P 500 absolute stock returns, Journal of Empirical Finance $11,399-421$.

Hassler, U., 2011, Estimation of fractional integration under temporal aggregation,Journal of Econometrics 162, 240-247.

Henning, C. R. 2012. Choice and Coercion in East Asian Exchange Rate Regimes. Working Paper 12-15. Washington: Peterson Institute for International Economics.

Hernandez, L., and P. J. Montiel. 2003. Post-crisis Exchange Rate Policy in Five Asian Countries: Filling the 'Hollow Middle'. Journal of the Japanese and International Economies 17: 336-369.

Ho, C., Ma, G., \& McCauley, R. (2005). Trading Asian currencies. BIS Quarterly Review, March: 49-58.

Holmes, M. J. (2002) Purchasing Power Parity and the Fractional Integration of Real Exchange Rate: New Evidence for Less Developed Countries, Journal of Economic Development, 27, 125-135.

Kawai, M. (2007). Toward a Regional Exchange Rate Regime in East Asia. ADBI Discussion Paper No. 68. Tokyo: ADBI.

Kawai, M. \& Pontines, V. (2014). The Renminbi and Exchange Rate Regimes in East Asia," ADBI Working Papers 484, Asian Development Bank Institute.

Kenen, P. and Meade E. (2008): Regional monetary integration, Cambridge University Press, Cambridge.

Levy-Yeyati, E., and F. Sturzenegger. 2003. To Float or to Trail: Evidence on the Impact of Exchange Rate Regimes. American Economic Review 93(4): 1173-1193.

Levy-Yeyati, E, and Sturzenegger, F. (2005). Classifying Exchange Rate Regimes: Deeds Vs. Words. European Economic Review, 49(6): 1603-35.

Ma, G. \& McCauley, R. (2010). The evolving renminbi regime and implications for Asian currency stability. BIS Working Papers 321, Bank for International Settlements.

McKinnon, R.I. and Schnabl, G., (2004). The return to soft dollar pegging in East Asia: mitigating conflicted virtue. International Finance (EcoWPA) 7, 169-201.

Mishra, R. K. and Sharma, C., (2010). Real exchange rate behavior and optimum currency area in East Asia: evidence from generalized purchasing power parity. International Review of Financial Analysis 19, 205-213. 
Mundell, Robert (2003): "Prospects for an Asian currency area”, Journal of Asian Economics 14, pp 1-10.

Ogawa, E. and Kawasaki, K. (2008). Adopting a common currency basket arrangement into the ASEAN Plus Three. NBER chapters.In: Ito, T., Rose, A.K. (Eds.), EBT International Financial Issues in the Pacific Rim: Global Imbalances, Financial Liberalization,and Exchange Rate Policy. EBST National Bureau of Economic Research: NBER-EASE, vol. 17, pp. 219-237.

Ogawa, E., and J. Shimizu. 2005. A Deviation Measurement for Coordinated Exchange Rate Policies in East Asia. Research Institute of Economy, Trade and Industry (RIETI) Discussion Paper Series 05-E-017. Tokyo: RIETI.

Park, Yung Chul (2008): "The regional currency unit and exchange rate policy cooperation in East Asia”, in Morris Goldstein and Nicholas R Lardy (eds.), Debating China's exchange rate policy, Peterson Institute for International Economics, Washington, pp 259-267.

Parke, W.R., 1999, What is fractional integration?, The Review of Economics andStatistics 81, 632-638.

Phillips, P.C.B., Shimotsu, K. (2004), Local Whittle estimation in nonstationary and unit root cases. Annals of Statistics 32, 656-692.

Phillips, P.C.B., Shimotsu, K. (2005), Exact local Whittle estimation in nonstationary and unit root cases. Annals of Statistics 33, 1890-1933.

Pontines, V. and Siregar R. Y. (2012) Fear of Appreciation in East and Southeast Asia: The Role of the Chinese Renminbi, Journal of Asian Economics 23 (4), 324-334.

Robinson, P.M. (1978) Statistical inference for a random coefficient autoregressive model, Scandinavian Journal of Statistics 5, 163-168.

Robinson, P.M. (1994) Efficient tests of nonstationary hypotheses, Journal of the American Statistical Association 89, 1420-1437.

Robinson, P.M. ,1995, Gaussian semiparametric estimation of long range dependence, Annals of Statistics, 23, 1630-1661.

Salidjanova, N., Koch-Weser, I. and Klanderman, J. (2015) China's economic ties with ASEAN: A Country-by-Country Analysis. Staff Research Report, U.S.-China Economic and Security Review Commission.

Soofi, A. S., S. Wang, and Zhang Y. (2006) Testing for long memory in the Asian foreign exchange rates, Journal of Systems Science and Complexity 19, 182-190.

Souza, L.R., (2005) A note on Chamber's long memory and aggregation in macroeconomic time series, International Economic Review 46, 3, 1059-1062. 
Sowell, F., 1992, Maximum likelihood estimation of stationary univariate fractionally integrated time series models, Journal of Econometrics 53, 165.188.

Subramanian, A. and Kessler, M (2012) The Renminbi Bloc is Here: Asia Down, Rest of the World to Go? Peterson Institute for International Economics Working Paper No. 12-19.

Sun, W. and Simons, G., (2011) Monetary integration in East Asia: evidence from real effective exchange rates. Review of International Economics 19, 865-876.

Taqqu, M.S., W. Willinger and R. Sherman, 1997, Proof of a fundamental result in self similar traffic modelling. Computer Communication Review 27, 5-23.

Volz, U. (2014) RMB Internationalisation and Currency Cooperation in East Asia, Financial and Monetary Policy Studies, 38, 57-81.

Wilson, P., and Choy, K.M., (2007) Prospects for enhanced exchange rate cooperation in East Asia: some preliminary findings fromGeneralized PPP theory. Applied Economics 39, 981-995.

You, K., and Sarantis, N. (2011). Structural Breaks and the Equilibrium Chinese Yuan/US Dollar Real Exchange Rate: A FEER Approach. Review of International Economics 19(5): 791-808.

You, K., and Sarantis, N. (2012a). A Twelve-Area Model for the Equilibrium Chinese Yuan/US Dollar Nominal Exchange Rate. Journal of International Financial Markets. Institutions and Money 22(1): 151-170.

You, K., and Sarantis, N. (2012b). Structural Breaks and the Equilibrium Real Effective Exchange Rate of China, A NATREX Approach. China Economic Review 23: 11461163. 
Table 1: Estimates of $d$ based on white noise errors

\begin{tabular}{|c|c|c|c|}
\hline \multicolumn{4}{|c|}{ i) ASEAN currencies vis-a-vis the regional index } \\
\hline Country & No regressors & An intercept & A linear time trend \\
\hline BRUNEI & $0.99(0.90,1.10)$ & $1.15(1.05,1.28)$ & $1.15(1.05,1.28)$ \\
\hline CAMBODIA & $0.98(0.90,1.09)$ & $1.07(0.97,1.20)$ & $1.07(0.97,1.20)$ \\
\hline INDONESIA & $0.98(0.90,1.09)$ & $1.00(0.89,1.15)$ & $1.00(0.89,1.15)$ \\
\hline LAO P. DEM. R. & $0.98(0.88,1.10)$ & $1.02(0.82,1.29)$ & 1.02 (0.82, 1.29) \\
\hline MALAYSIA & $1.01(0.92,1.12)$ & $1.02(0.89,1.19)$ & $1.02(0.89,1.19)$ \\
\hline PHILLIPPINES & $1.01(0.92,1.12)$ & $1.09(0.98,1.25)$ & $1.09(0.98,1.25)$ \\
\hline SINGAPORE & $1.01(0.93,1.12)$ & 1.19 (1.08, 1.32) & 1.19 (1.08, 1.32) \\
\hline THAILAND & $0.98(0.90,1.09)$ & $1.00(0.89,1.13)$ & $1.00(0.89,1.13)$ \\
\hline VIETNAM & $1.01(0.92,1.12)$ & $1.16(1.06,1.29)$ & $1.17(1.06,1.29)$ \\
\hline \multicolumn{4}{|c|}{ ii) ASEAN currencies vis-a-vis the US dollar } \\
\hline Country & No regressors & An intercept & A linear time trend \\
\hline BRUNEI & $0.98(0.90,1.08)$ & $1.10(1.01,1.24)$ & $1.10(1.01,1.24)$ \\
\hline CAMBODIA & $0.99(0.91,1.09)$ & $1.13(1.05,1.24)$ & $1.13(1.05,1.24)$ \\
\hline INDONESIA & $0.96(0.87,1.09)$ & $0.95(0.85,1.09)$ & $0.95(0.85,1.09)$ \\
\hline LAO P. DEM. R. & $1.03(0.94,1.15)$ & $1.18(1.04,1.35)$ & $1.18(1.04,1.35)$ \\
\hline MALAYSIA & $1.02(0.94,1.13)$ & $1.05(0.97,1.17)$ & $1.05(0.97,1.17)$ \\
\hline PHILLIPPINES & $1.04(0.96,1.14)$ & $1.22(1.12,1.36)$ & $1.22(1.12,1.36)$ \\
\hline SINGAPORE & $1.00(0.93,1.11)$ & $1.11(1.03,1.22)$ & $1.11(1.03,1.22)$ \\
\hline THAILAND & $1.03(0.94,1.14)$ & $1.15(1.04,1.31)$ & $1.15(1.04,1.31)$ \\
\hline VIETNAM & $0.97(0.89,1.08)$ & $1.02(0.95,1.11)$ & $1.02(0.95,1.11)$ \\
\hline \multicolumn{4}{|c|}{ iii) ASEAN currencies vis-a-vis the RMB } \\
\hline Country & No regressors & An intercept & A linear time trend \\
\hline BRUNEI & $1.00(0.92,1.10)$ & $1.03(0.91,1.19)$ & $1.03(0.91,1.19)$ \\
\hline CAMBODIA & $0.99(0.91,1.10)$ & $1.03(0.91,1.17)$ & $1.02(0.91,1.17)$ \\
\hline INDONESIA & $0.96(0.87,1.09)$ & $0.95(0.85,1.09)$ & $0.95(0.85,1.09)$ \\
\hline LAO P. DEM. R. & $1.05(0.96,1.18)$ & $1.19(1.06,1.36)$ & $1.19(1.06,1.36)$ \\
\hline MALAYSIA & $1.05(0.96,1.17)$ & $1.05(0.95,1.18)$ & $1.05(0.95,1.18)$ \\
\hline PHILLIPPINES & $1.04(0.96,1.15)$ & $1.18(1.07,1.34)$ & $1.18(1.07,1.34)$ \\
\hline SINGAPORE & $1.02(0.95,1.15)$ & $1.03(0.92,1.19)$ & $1.03(0.93,1.18)$ \\
\hline THAILAND & $1.04(0.95,1.15)$ & $1.12(1.00,1.29)$ & $1.12(1.00,1.29)$ \\
\hline VIETNAM & $1.02(0.94,1.13)$ & $1.14(1.07,1.25)$ & $1.15(1.07,1.25)$ \\
\hline
\end{tabular}


Table 2: Estimates of $\mathbf{d}$ based on autocorrelated errors

\begin{tabular}{|c|c|c|c|}
\hline \multicolumn{4}{|c|}{ i) ASEAN currencies vis-a-vis the regional index } \\
\hline Country & No regressors & An intercept & A linear time trend \\
\hline BRUNEI & $0.94(0.79,1.12)$ & $0.94(0.78,1.13)$ & $0.94(0.78,1.13)$ \\
\hline CAMBODIA & $0.90(0.78,1.07)$ & $0.85(0.69,1.03)$ & $0.85(0.71,1.03)$ \\
\hline INDONESIA & $0.92(0.79,1.08)$ & $0.75(0.60,0.94)$ & $0.75(0.60,0.94)$ \\
\hline LAO P. DEM. R. & $0.82(0.72,0.96)$ & $0.48(0.40,0.58)$ & $0.32(0.19,0.49)$ \\
\hline MALAYSIA & $0.92(0.79,1.10)$ & $0.64(0.52,0.78)$ & $0.63(0.48,0.78)$ \\
\hline PHILLIPPINES & $0.95(0.82,1.15)$ & $0.83(0.72,0.99)$ & $0.83(0.72,0.99)$ \\
\hline SINGAPORE & $0.96(0.81,1.16)$ & $0.90(0.75,1.10)$ & $0.90(0.75,1.10)$ \\
\hline THAILAND & $0.95(0.81,1.13)$ & $0.88(0.68,1.16)$ & $0.88(0.68,1.16)$ \\
\hline VIETNAM & $0.93(0.80,1.12)$ & $0.96(0.85,1.11)$ & $0.96(0.85,1.11)$ \\
\hline \multicolumn{4}{|c|}{ ii) ASEAN currencies vis-a-vis the US dollar } \\
\hline Country & No regressors & An intercept & A linear time trend \\
\hline BRUNEI & $0.95(0.84,1.11)$ & $0.90(0.82,1.03)$ & $0.91(0.83,1.03)$ \\
\hline CAMBODIA & $0.94(0.83,1.09)$ & $1.05(0.95,1.19)$ & $1.05(0.95,1.19)$ \\
\hline INDONESIA & $0.80(0.69,0.95)$ & $0.73(0.60,0.91)$ & $0.73(0.60,0.91)$ \\
\hline LAO P. DEM. R. & $0.91(0.80,1.05)$ & $0.86(0.75,1.06)$ & $0.87(0.74,1.06)$ \\
\hline MALAYSIA & $0.97(0.85,1.14)$ & $0.94(0.83,1.09)$ & $0.94(0.83,1.09)$ \\
\hline PHILLIPPINES & $1.01(0.89,1.18)$ & $0.98(0.89,1.12)$ & $0.98(0.89,1.12)$ \\
\hline SINGAPORE & $0.98(0.86,1.15)$ & $0.99(0.90,1.11)$ & $0.99(0.90,1.11)$ \\
\hline THAILAND & $0.94(0.82,1.10)$ & $0.84(0.73,0.97)$ & $0.84(0.74,0.97)$ \\
\hline VIETNAM & $0.93(0.80,1.11)$ & $1.03(0.92,1.17)$ & $1.03(0.92,1.17)$ \\
\hline \multicolumn{4}{|c|}{ iii) ASEAN currencies vis-a-vis the RMB } \\
\hline Country & No regressors & An intercept & A linear time trend \\
\hline BRUNEI & $0.96(0.84,1.13)$ & $0.66(0.84,1.11)$ & $0.71(0.60,0.88)$ \\
\hline CAMBODIA & $0.92(0.82,1.09)$ & $0.77(0.83,1.09)$ & $0.79(0.68,0.97)$ \\
\hline INDONESIA & $0.81(0.67,0.96)$ & $0.74(0.69,0.95)$ & $0.75(0.59,0.92)$ \\
\hline LAO P. DEM. R. & $0.91(0.80,1.08)$ & $0.85(0.70,1.05)$ & $0.85(0.70,1.10)$ \\
\hline MALAYSIA & $0.96(0.84,1.16)$ & $0.84(0.68,1.14)$ & $0.87(0.73,1.05)$ \\
\hline PHILLIPPINES & $0.99(0.87,1.18)$ & $0.83(0.69,1.18)$ & $0.85(0.73,0.99)$ \\
\hline SINGAPORE & $0.98(0.85,1.16)$ & $0.73(0.59,1.15)$ & $0.77(0.67,0.91)$ \\
\hline THAILAND & $0.91(0.80,1.08)$ & $0.72(0.58,1.10)$ & $0.76(0.62,0.92)$ \\
\hline VIETNAM & $0.98(0.87,1.16)$ & $1.06(0.99,1.11)$ & $1.07(0.99,1.20)$ \\
\hline
\end{tabular}


Table 3: Estimates of $\mathbf{d}$ based on autocorrelated errors

\begin{tabular}{|c|c|c|c|c|c|c|c|c|c|}
\hline \multicolumn{10}{|c|}{ currencies vis-a-vis the regional index } \\
\hline Country & 11 & 12 & 13 & 14 & 15 & 16 & 17 & 18 & 19 \\
\hline BRUNEI & 0.694 & 0.720 & 0.748 & 0.739 & 0.768 & 0.788 & 0.832 & 0.877 & 0.931 \\
\hline CAMBODIA & 0.735 & 0.810 & 0.839 & 0.838 & 0.838 & 0.838 & 0.897 & 0.945 & 0.995 \\
\hline INDONESIA & 0.567 & 0.603 & 0.610 & 0.620 & 0.641 & 0.653 & 0.674 & 0.693 & 0.698 \\
\hline LAO P. DEM. R. & 0.500 & 0.500 & 0.500 & 0.500 & 0.500 & 0.500 & 0.549 & 0.619 & 0.651 \\
\hline MALAYSIA & 0.574 & 0.640 & 0.644 & 0.671 & 0.696 & 0.686 & 0.707 & 0.745 & 0.764 \\
\hline PHILLIPPINES & 1.013 & 0.999 & 1.019 & 1.036 & 1.017 & 0.971 & 0.978 & 0.892 & 0.876 \\
\hline SINGAPORE & 0.652 & 0.675 & 0.711 & 0.713 & 0.749 & 0.771 & 0.820 & 0.874 & 0.931 \\
\hline THAILAND & 0.500 & 0.500 & 0.500 & 0.500 & 0.500 & 0.535 & 0.559 & 0.577 & 0.592 \\
\hline VIETNAM & 0.947 & 1.000 & 0.961 & 0.967 & 1.000 & 0.998 & 1.040 & 1.079 & 1.082 \\
\hline \multicolumn{10}{|c|}{ ii) ASEAN currencies vis-a-vis the US dollar } \\
\hline Country & 11 & 12 & 13 & 14 & 15 & 16 & 17 & 18 & 19 \\
\hline BRUNEI & 1.293 & 1.277 & 1.138 & 1.088 & 1.113 & 1.130 & 1.144 & 1.114 & 1.090 \\
\hline CAMBODIA & 1.114 & 1.138 & 1.094 & 1.105 & 1.109 & 1.135 & 1.135 & 1.088 & 1.088 \\
\hline INDONESIA & 0.600 & 0.633 & 0.627 & 0.646 & 0.669 & 0.689 & 0.711 & 0.739 & 0.754 \\
\hline LAO P. DEM. R. & 0.973 & 0.870 & 0.838 & 0.846 & 0.844 & 0.837 & 0.836 & 0.859 & 0.889 \\
\hline MALAYSIA & 0.995 & 1.035 & 1.008 & 1.017 & 1.045 & 1.052 & 1.088 & 1.103 & 1.123 \\
\hline PHILLIPPINES & 1.128 & 1.190 & 1.112 & 1.151 & 1.180 & 1.216 & 1.248 & 1.248 & 1.242 \\
\hline SINGAPORE & 1.323 & 1.322 & 1.213 & 1.174 & 1.200 & 1.223 & 1.242 & 1.201 & 1.186 \\
\hline THAILAND & 0.731 & 0.710 & 0.778 & 0.801 & 0.883 & 0.897 & 0.934 & 0.934 & 0.966 \\
\hline VIETNAM & 1.500 & 1.500 & 1.500 & 1.500 & 1.431 & 1.304 & 1.177 & 1.161 & 1.161 \\
\hline \multicolumn{10}{|c|}{ iii) ASEAN currencies vis-a-vis the RMB } \\
\hline Country & 11 & 12 & 13 & 14 & 15 & 16 & 17 & 18 & 19 \\
\hline BRUNEI & 1.049 & 1.002 & 0.842 & 0.826 & 0.861 & 0.881 & 0.911 & 0.907 & 0.939 \\
\hline CAMBODIA & 0.869 & 0.905 & 0.818 & 0.833 & 0.848 & 0.880 & 0.900 & 0.862 & 0.884 \\
\hline INDONESIA & 0.590 & 0.628 & 0.619 & 0.636 & 0.659 & 0.680 & 0.706 & 0.736 & 0.758 \\
\hline LAO P. DEM. R. & 0.860 & 0.776 & 0.748 & 0.755 & 0.756 & 0.750 & 0.760 & 0.788 & 0.818 \\
\hline MALAYSIA & 0.873 & 0.935 & 0.891 & 0.897 & 0.927 & 0.942 & 0.992 & 1.023 & 1.067 \\
\hline PHILLIPPINES & 0.861 & 0.925 & 0.860 & 0.899 & 0.930 & 0.977 & 1.028 & 1.036 & 1.054 \\
\hline SINGAPORE & 1.154 & 1.109 & 0.958 & 0.944 & 0.976 & 1.000 & 1.031 & 1.012 & 1.044 \\
\hline THAILAND & 0.773 & 0.780 & 0.749 & 0.773 & 0.757 & 0.775 & 0.817 & 0.827 & 0.863 \\
\hline VIETNAM & 1.406 & 1.407 & 1.448 & 1.477 & 1.500 & 1.473 & 1.386 & 1.400 & 1.329 \\
\hline
\end{tabular}


Table 4: Testing for a single break with Bai and Perron $(1998,2003)$ tests

\begin{tabular}{|c|c|c|c|}
\hline & $\begin{array}{c}\text { Vis-a-vis Regional } \\
\text { Index }\end{array}$ & Vis-a-vis USD & Vis-a-vis RMB \\
\hline BRUNEI & $2005 \mathrm{M} 10$ & $1998 \mathrm{M} 01$ & $1998 \mathrm{M} 01$ \\
\hline CAMBODIA & $1998 \mathrm{M} 01$ & $2008 \mathrm{M} 03$ & $1998 \mathrm{M} 01$ \\
\hline INDONESIA & $2002 \mathrm{M} 05$ & $2005 \mathrm{M} 12$ & $2002 \mathrm{M} 05$ \\
\hline LAO & $2008 \mathrm{M} 04$ & $2008 \mathrm{M} 02$ & $2006 \mathrm{M} 03$ \\
\hline MALAYSIA & $2003 \mathrm{M} 05$ & $1998 \mathrm{M} 01$ & $1998 \mathrm{M} 01$ \\
\hline PHILIPPINES & $2002 \mathrm{M} 03$ & $2007 \mathrm{M} 11$ & $1998 \mathrm{M} 01$ \\
\hline SINGAPORE & $1998 \mathrm{M} 01$ & $2010 \mathrm{M} 08$ & $1998 \mathrm{M} 01$ \\
\hline THAILAND & $1998 \mathrm{M} 01$ & $2007 \mathrm{M} 05$ & $1998 \mathrm{M} 01$ \\
\hline VIETNAM & $2009 \mathrm{M} 09$ & $2009 \mathrm{M} 11$ & $2008 \mathrm{M} 06$ \\
\hline
\end{tabular}


Table 5: Testing for multiple breaks with Bai and Perron $(1998,2003)$ tests

\begin{tabular}{|c|c|c|c|}
\hline & $\begin{array}{l}\text { Vis-a-vis Regional } \\
\text { Index }\end{array}$ & Vis-a-vis USD & Vis-a-vis RMB \\
\hline BRUNEI & $\begin{array}{l}\text { 1998M01 } \\
\text { 2001M12 } \\
\text { 2005M10 }\end{array}$ & $\begin{array}{l}\text { 1998M01 } \\
\text { 2001M02 } \\
\text { 2006M10 } \\
\text { 2010M08 }\end{array}$ & $\begin{array}{l}\text { 1998M01 } \\
\text { 2001M02 } \\
\text { 2008M01 } \\
\text { 2011M11 }\end{array}$ \\
\hline CAMBODIA & $\begin{array}{l}\text { 1998M01 } \\
\text { 2002M05 } \\
\text { 2008M03 }\end{array}$ & $\begin{array}{l}\text { 1998M01 } \\
\text { 2001M01 } \\
\text { 2005M03 } \\
\text { 2008M03 } \\
\text { 2011M04 }\end{array}$ & $\begin{array}{l}\text { 1998M01 } \\
\text { 2008M03 } \\
\text { 2011M06 }\end{array}$ \\
\hline INDONESIA & $\begin{array}{l}\text { 1998M01 } \\
\text { 2002M04 }\end{array}$ & $\begin{array}{l}\text { 1998M01 } \\
\text { 2002M04 } \\
\text { 2006M01 } \\
\text { 2009M10 }\end{array}$ & $\begin{array}{l}\text { 1998M01 } \\
\text { 2002M04 } \\
\text { 2012M01 }\end{array}$ \\
\hline LAO & $\begin{array}{l}\text { 1998M01 } \\
\text { 2002M04 }\end{array}$ & $\begin{array}{l}\text { 1998M01 } \\
\text { 2004M04 } \\
\text { 2008M01 } \\
\text { 2011M02 }\end{array}$ & $\begin{array}{l}\text { 1998M01 } \\
\text { 2003M03 } \\
\text { 2006M03 } \\
\text { 2010M04 }\end{array}$ \\
\hline MALAYSIA & $\begin{array}{l}\text { 1998M01 } \\
\text { 2002M12 } \\
\text { 2006M05 }\end{array}$ & $\begin{array}{l}\text { 1998M01 } \\
\text { 2006M12 } \\
\text { 2010M10 }\end{array}$ & $\begin{array}{l}\text { 1998M01 } \\
\text { 2001M02 } \\
\text { 2008M09 } \\
\text { 2011M11 }\end{array}$ \\
\hline PHILLIPPINES & $\begin{array}{l}\text { 1998M01 } \\
\text { 2002M04 } \\
\text { 2007M06 } \\
\text { 2012M01 }\end{array}$ & $\begin{array}{l}\text { 1998M01 } \\
\text { 2001M01 } \\
\text { 2004M11 } \\
\text { 2007M11 } \\
2010 \mathrm{M} 11\end{array}$ & $\begin{array}{l}\text { 1998M01 } \\
\text { 2001M01 } \\
\text { 2005M12 }\end{array}$ \\
\hline SINGAPORE & $\begin{array}{l}\text { 1998M01 } \\
2002 \mathrm{M} 01 \\
2005 \mathrm{M} 10 \\
2008 \mathrm{M} 10 \\
2012 \mathrm{M} 01\end{array}$ & $\begin{array}{l}\text { 1998M01 } \\
\text { 2001M01 } \\
\text { 2007M08 } \\
\text { 2010M10 }\end{array}$ & $\begin{array}{l}\text { 1998M01 } \\
\text { 2001M01 } \\
\text { 2007M06 } \\
\text { 2010M07 }\end{array}$ \\
\hline THAILAND & $\begin{array}{l}\text { 1998M01 } \\
\text { 2001M07 } \\
\text { 2007M03 } \\
\text { 2012M01 }\end{array}$ & $\begin{array}{l}\text { 1998M01 } \\
\text { 2001M01 } \\
\text { 2004M01 } \\
\text { 2007M01 } \\
\text { 2010M05 }\end{array}$ & $\begin{array}{l}\text { 1998M01 } \\
\text { 2001M01 } \\
\text { 2007M06 } \\
\text { 2010M07 }\end{array}$ \\
\hline VIETNAM & $\begin{array}{l}\text { 1998M01 } \\
\text { 2002M05 } \\
\text { 2006M02 } \\
\text { 2010M01 }\end{array}$ & $\begin{array}{l}\text { 1998M02 } \\
\text { 2001M10 } \\
\text { 2006M06 } \\
\text { 2010M03 }\end{array}$ & $\begin{array}{l}\text { 1998M01 } \\
\text { 2005M06 } \\
\text { 2008M06 } \\
\text { 2011M06 }\end{array}$ \\
\hline
\end{tabular}


Table 6: Estimates for the ASEAN currencies vis-a-vis the regional index

\begin{tabular}{|c|c|c|c|}
\hline Country & Breaks & Subsamples & $d$ \\
\hline \multirow{4}{*}{ BRUNEI } & \multirow{4}{*}{3} & 1995M01 - 1997M12 & $1.18(0.94,1.48)$ \\
\hline & & 1998M01 - 2001M11 & $1.13 \quad(0.89, \quad 1.55)$ \\
\hline & & 2001M12 - 2005M09 & $0.95 \quad(0.74, \quad 1.19)$ \\
\hline & & 2005M10 - 2014M12 & $1.01 \quad(0.85,1.22)$ \\
\hline \multirow{4}{*}{ CAMBODIA } & \multirow{4}{*}{3} & 1995M01 - 1997M12 & $1.02(0.77,1.31)$ \\
\hline & & 1998M01 - 2002M04 & $1.05(0.61,1.53)$ \\
\hline & & 2002M05 - 2008M02 & 1.14 (0.96, 1.39) \\
\hline & & 2008M03 - 2014M12 & 1.09 (0.95, 1.36) \\
\hline \multirow{3}{*}{ INDONESIA } & \multirow{3}{*}{2} & 1995M01 - 1997M12 & $0.39(-0.09,0.98)$ \\
\hline & & 1998M01 - 2002M03 & $0.89 \quad(0.61, \quad 1.32)$ \\
\hline & & 2002M04 - 2014M12 & 1.02 (0.89, 1.19) \\
\hline \multirow{3}{*}{ LAO } & \multirow{3}{*}{2} & 1995M01 - 1997M12 & $0.72(0.44,1.17)$ \\
\hline & & 1998M01 - 2002M03 & $1.10 \quad(0.67,1.72)$ \\
\hline & & 2002M04 - 2014M12 & $1.14(1.00,1.33)$ \\
\hline \multirow{4}{*}{ MALAYSIA } & \multirow{4}{*}{3} & 1995M01 - 1997M12 & $0.32(0.11,0.82)$ \\
\hline & & 1998M01 - 2002M11 & $0.94 \quad(0.75,1.23)$ \\
\hline & & 2002M12 - 2006M04 & $1.04(0.75,1.36)$ \\
\hline & & 2006M05 - 2014M12 & $0.96(0.71,1.36)$ \\
\hline \multirow{5}{*}{ PHILLIPPINES } & \multirow{5}{*}{4} & 1995M01 - 1997M12 & $0.76(0.45,1.32)$ \\
\hline & & 1998M01 - 2002M03 & $0.82(0.47,1.46)$ \\
\hline & & 2002M04 - 2007M05 & 1.10 (0.97, 1.29) \\
\hline & & 2007M06 - 2011M12 & $1.13(0.88,1.44)$ \\
\hline & & 2012M01 - 2011M12 & $1.23(0.55,1.92)$ \\
\hline
\end{tabular}

(CONT.) 


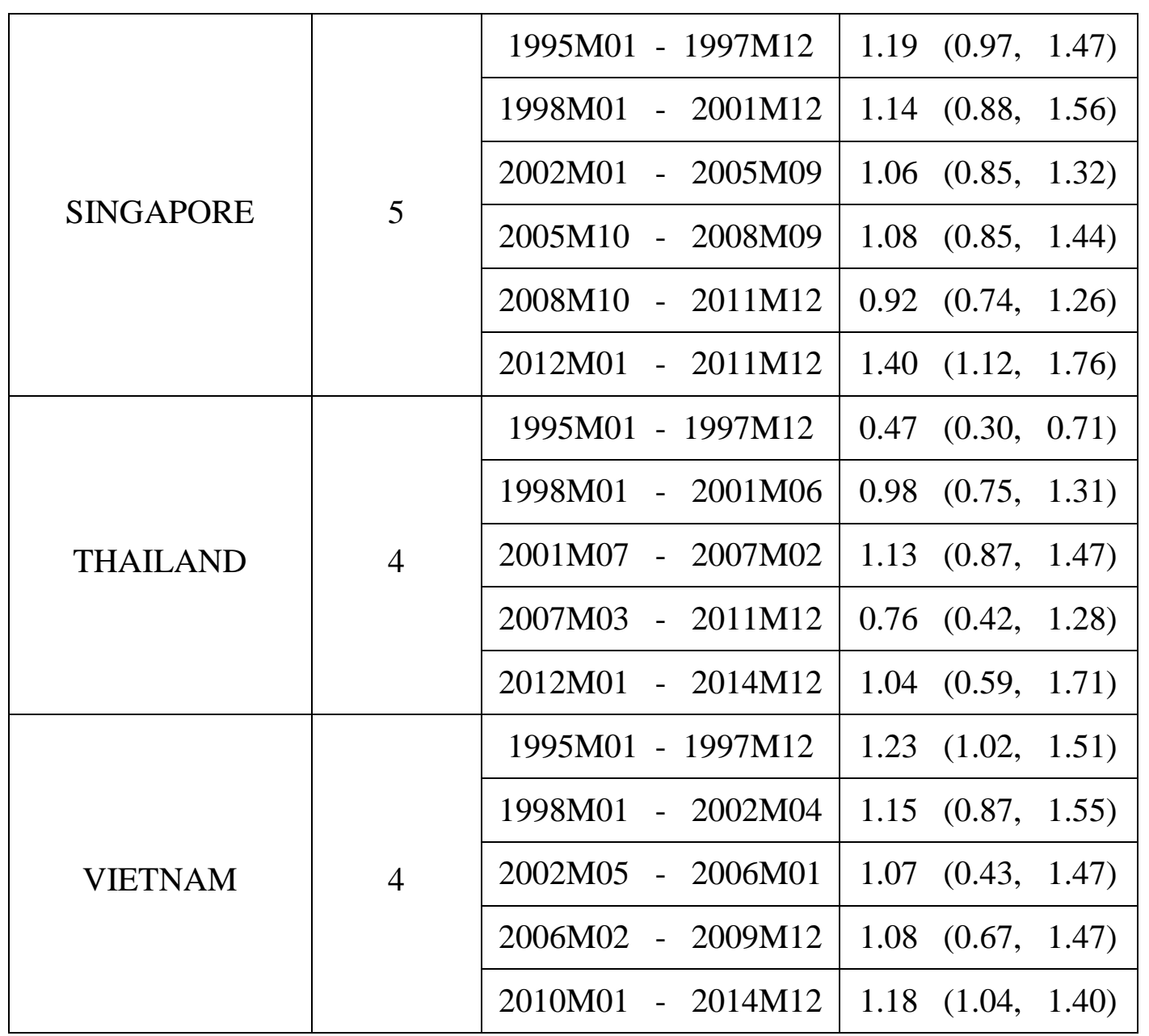


Table 7: Estimates for the ASEAN currencies vis-a-vis the US dollar

\begin{tabular}{|c|c|c|c|}
\hline Country & Breaks & Subsamples & $\mathrm{d}$ \\
\hline \multirow{5}{*}{ BRUNEI } & \multirow{5}{*}{4} & 1995M01 - 1997M12 & $1.35(1.10,1.77)$ \\
\hline & & 1998M01 - 2001M01 & $1.10 \quad(0.62,1.76)$ \\
\hline & & 2001M02 - 2006M09 & $1.01(0.70,1.40)$ \\
\hline & & 2006M10 - 2010M07 & $0.96(0.59,1.31)$ \\
\hline & & 2010M08 - 2014M12 & $1.09(0.84, \quad 1.49)$ \\
\hline \multirow{6}{*}{ CAMBODIA } & \multirow{6}{*}{5} & 1995M01 - 1997M12 & $0.93(0.71,1.22)$ \\
\hline & & 1998M01 - 2000M12 & $0.77 \quad(0.52,1.59)$ \\
\hline & & 2001M01 - 2005M02 & $0.76(0.58,1.05)$ \\
\hline & & 2005M03 - 2008M02 & $1.15(0.98,1.41)$ \\
\hline & & 2008M03 - 2011M03 & $1.45(1.04,2.41)$ \\
\hline & & 2011M04 - 2014M12 & $1.06(0.77,1.52)$ \\
\hline \multirow{5}{*}{ INDONESIA } & \multirow{5}{*}{4} & 1995M01 - 1997M12 & $1.01 \quad(0.62,1.41)$ \\
\hline & & 1998M01 - 2002M03 & $0.96 \quad(0.59,1.45)$ \\
\hline & & 2002M04 - 2005M12 & $0.95(0.39,1.34)$ \\
\hline & & 2006M01 - 2009M09 & $0.92(0.60,1.30)$ \\
\hline & & 2009M10 - 2014M12 & $1.14(0.99,1.40)$ \\
\hline \multirow{5}{*}{ LAO } & \multirow{5}{*}{4} & 1995M01 - 1997M12 & $1.49(1.25, \quad 1.75)$ \\
\hline & & 1998M01 - 2004M03 & $1.12(0.78,1.48)$ \\
\hline & & 2004M04 - 2007M12 & $0.93(1.83,1.13)$ \\
\hline & & 2008M01 - 2011M01 & $1.42(1.14, \quad 1.79)$ \\
\hline & & 2011M02 - 2014M12 & $1.48 \quad(1.21, \quad 1.88)$ \\
\hline \multirow{4}{*}{ MALAYSIA } & \multirow{4}{*}{3} & 1995M01 - 1997M12 & 1.53 (1.33, 1.79) \\
\hline & & 1998M01 - 2006M11 & $1.07 \quad(0.27,1.53)$ \\
\hline & & 2006M12 - 2010M09 & $1.14(0.93,1.46)$ \\
\hline & & 2010M10 - 2014M12 & $0.92(0.52,1.60)$ \\
\hline
\end{tabular}

(CONT.) 


\begin{tabular}{|c|c|c|c|}
\hline \multirow{6}{*}{ PHILLIPPINES } & \multirow{6}{*}{5} & 1995M01 - 1997M12 & $1.45(1.25,1.77)$ \\
\hline & & 1998M01 - 2000M12 & $1.61(1.15,2.22)$ \\
\hline & & 2001M01 - 2004M10 & $0.85(0.63,1.34)$ \\
\hline & & 2004M11 - 2007M10 & $1.49 \quad(0.77,2.31)$ \\
\hline & & 2007M11 - 2010M10 & $1.13(0.82,1.70)$ \\
\hline & & 2010M11 - 2014M12 & $1.08 \quad(0.87,1.39)$ \\
\hline \multirow{5}{*}{ SINGAPORE } & \multirow{5}{*}{4} & 1995M01 - 1997M12 & $1.31(1.07,1.70)$ \\
\hline & & 1998M01 - 2000M12 & $1.09(0.54,1.83)$ \\
\hline & & 2001M01 - 2007M07 & $0.96(0.77,1.22)$ \\
\hline & & 2007M08 - 2010M09 & $1.15(0.86,1.49)$ \\
\hline & & 2010M10 - 2014M12 & $1.03(0.81,1.38)$ \\
\hline \multirow{6}{*}{ THAILAND } & \multirow{6}{*}{5} & 1995M01 - 1997M12 & $1.29(1.10,1.57)$ \\
\hline & & 1998M01 - 2000M12 & $1.73(1.18,2.14)$ \\
\hline & & 2001M01 - 2003M12 & $1.06(0.81,1.51)$ \\
\hline & & 2004M01 - 2006M12 & $1.23(1.00,1.57)$ \\
\hline & & 2007M01 - 2010M04 & $1.36(1.16,1.64)$ \\
\hline & & 2010M05 - 2014M12 & $1.22(0.97,1.66)$ \\
\hline \multirow{5}{*}{ VIETNAM } & \multirow{5}{*}{4} & 1995M01 - 1997M12 & $1.25(1.06,1.69)$ \\
\hline & & 1998M01 - 2001M09 & $0.78 \quad(0.57,1.24)$ \\
\hline & & 2001M10 - 2006M05 & $0.76 \quad(0.67,1.13)$ \\
\hline & & 2006M06 - 2010M02 & $1.09 \quad(0.88,1.37)$ \\
\hline & & 2010M03 - 2014M12 & $1.12(0.92,1.41)$ \\
\hline
\end{tabular}


Table 8: Estimates for the ASEAN currencies vis-a-vis the RMB

\begin{tabular}{|c|c|c|c|}
\hline Country & Breaks & Subsamples & $\mathrm{d}$ \\
\hline \multirow{5}{*}{ BRUNEI } & \multirow{5}{*}{4} & 1995M01 - 1997M12 & $1.11(0.76,1.63)$ \\
\hline & & 1998M01 - 2001M01 & $0.57 \quad(-0.01,1.56)$ \\
\hline & & 2001M02 - 2007M12 & $0.98 \quad(0.73,1.32)$ \\
\hline & & 2008M01 - 2011M10 & $1.10 \quad(0.82, \quad 1.45)$ \\
\hline & & 2011M11 - 2014M12 & $1.05(0.78,1.54)$ \\
\hline \multirow{4}{*}{ CAMBODIA } & \multirow{4}{*}{3} & 1995M01 - 1997M12 & $0.85 \quad(0.61,1.19)$ \\
\hline & & 1998M01 - 2008M02 & $0.90 \quad(0.70,1.16)$ \\
\hline & & 2008M03 - 2011M05 & 1.39 (0.99, 1.81) \\
\hline & & 2011M06 - 2014M12 & $0.92(0.28,1.44)$ \\
\hline \multirow{4}{*}{ INDONESIA } & \multirow{4}{*}{4} & 1995M01 - 1997M12 & $0.97 \quad(0.43,1.41)$ \\
\hline & & 1998M01 - 2002M03 & $0.95 \quad(0.57,1.39)$ \\
\hline & & 2002M04 - 2011M12 & $1.06 \quad(0.92,1.26)$ \\
\hline & & 2012M01 - 2014M12 & $1.10(0.84, \quad 1.55)$ \\
\hline \multirow{5}{*}{ LAO } & \multirow{5}{*}{4} & 1995M01 - 1997M12 & $1.50(1.27, \quad 1.76)$ \\
\hline & & 1998M01 - 2003M02 & $1.12(0.55,1.50)$ \\
\hline & & 2003M03 - 2006M02 & $1.19(0.40,1.67)$ \\
\hline & & 2006M03 - 2010M03 & $1.19(0.74,1.62)$ \\
\hline & & 2010M04 - 2014M12 & 1.64 (1.22, 2.11) \\
\hline \multirow{5}{*}{ MALAYSIA } & \multirow{5}{*}{4} & 1995M01 - 1997M12 & $1.47(1.23,1.80)$ \\
\hline & & 1998M01 - 2001M01 & $0.33 \quad(0.19,1.61)$ \\
\hline & & 2001M02 - 2008M08 & $1.00 \quad(0.83,1.28)$ \\
\hline & & 2008M09 - 2011M10 & $1.22(0.94,1.58)$ \\
\hline & & 2011M11 - 2014M12 & $1.09(0.61,1.79)$ \\
\hline \multirow{4}{*}{ PHILLIPPINES } & \multirow{4}{*}{3} & 1995M01 - 1997M12 & $1.37(1.13,1.79)$ \\
\hline & & 1998M01 - 2000M12 & $1.55(1.09,2.12)$ \\
\hline & & 2001M01 - 2005M11 & $1.13(0.81,1.66)$ \\
\hline & & 2004M11 - 2014M12 & 1.13 (0.96, 1.38) \\
\hline
\end{tabular}


(CONT.)

\begin{tabular}{|c|c|c|c|}
\hline \multirow{5}{*}{ SINGAPORE } & \multirow{5}{*}{4} & 1995M01 - 1997M12 & $1.06 \quad(0.57,1.72)$ \\
\hline & & 1998M01 - 2000M12 & $0.36 \quad(-0.14,1.64)$ \\
\hline & & 2001M01 - 2007M05 & $1.00 \quad(0.74,1.33)$ \\
\hline & & 2007M06 - 2010M06 & $1.03(0.78,1.46)$ \\
\hline & & 2010M07 - 2014M12 & $1.13(0.86,1.51)$ \\
\hline \multirow{5}{*}{ THAILAND } & \multirow{5}{*}{4} & 1995M01 - 1997M12 & $1.24 \quad(1.02,1.52)$ \\
\hline & & 1998M01 - 2000M12 & $1.63(1.13,2.27)$ \\
\hline & & 2001M01 - 2007M05 & $1.05(0.83,1.38)$ \\
\hline & & 2007M06 - 2010M06 & $1.27 \quad(1.07,1.56)$ \\
\hline & & 2010M07 - 2014M12 & $1.17(0.86,1.62)$ \\
\hline \multirow{5}{*}{ VIETNAM } & \multirow{5}{*}{4} & 1995M01 - 1997M12 & $0.75 \quad(0.57,1.68)$ \\
\hline & & 1998M01 - 2005M05 & $0.75 \quad(0.52,1.07)$ \\
\hline & & 2005M06 - 2008M05 & 1.25 (1.01, 1.73) \\
\hline & & 2008M06 - 2011M05 & $1.04(0.88,1.34)$ \\
\hline & & 2011M06 - 2014M12 & 1.53 (1.16, 1.93) \\
\hline
\end{tabular}


Table 9: Estimates of $d$ for the two subsamples using Gil-Alana (2008) and white noise $u_{t}$

\begin{tabular}{|c|c|c|c|}
\hline & Vis-a-vis Reg. & Vis-a-vis USD & Vis-a-vis RMB \\
\hline Brunei $1^{\text {st }}$ subsample & $1.18(1.05,1.35)$ & $1.47 \quad(1.15,2.01)$ & $1.29(0.93,2.02)$ \\
\hline Brunei $2^{\text {nd }}$ subsample & $1.01 \quad(0.85,1.22)$ & 1.08 (0.97, 1.25) & $1.02(0.89,1.21)$ \\
\hline Cambodia $1^{\text {st }}$ subsample & $0.99 \quad(0.83,1.22)$ & $1.13(1.03,1.26)$ & $0.90 \quad(0.67,1.21)$ \\
\hline Cambodia $2^{\text {nd }}$ subsample & $1.11(0.98,1.30)$ & 1.28 (1.08, 1.61) & $1.01(0.86,1.20)$ \\
\hline Indonesia $1^{\text {st }}$ subsample & $1.00 \quad(0.82,1.24)$ & $0.95 \quad(0.82,1.14)$ & $0.94 \quad(0.78,1.17)$ \\
\hline Indonesia $2^{\text {nd }}$ subsample & $1.02(0.89,1.20)$ & $1.03(0.90,1.23)$ & $1.09 \quad(0.97,1.25)$ \\
\hline Laos $1^{\text {st }}$ subsample & $1.01(0.76,1.35)$ & 1.17 (1.02, 1.38) & 1.19 (1.02, 1.41) \\
\hline Laos $2^{\text {nd }}$ subsample & $1.14(0.98,1.38)$ & $1.36(1.17,1.60)$ & $1.31(1.08,1.58)$ \\
\hline Malaysia $1^{\text {st }}$ subsample & $1.03(0.85,1.29)$ & 1.80 (1.47, 2.35) & $1.77(1.38,2.44)$ \\
\hline Malaysia $2^{\text {nd }}$ subsample & $0.98 \quad(0.79,1.27)$ & $1.06(0.93,1.24)$ & $1.09(0.96,1.28)$ \\
\hline Philippines $1^{\text {st }}$ subsample & $1.07(0.88,1.38)$ & 1.22 (1.10, 1.39) & 1.62 (1.22, 2.54) \\
\hline Philippines $2^{\text {nd }}$ subsample & 1.14 (1.02, 1.29) & $1.06(0.91,1.31)$ & $1.20(1.06,1.38)$ \\
\hline Singapore $1^{\text {st }}$ subsample & $1.14(0.99,1.37)$ & 1.09 (1.00, 1.22) & $1.39(0.55,2.33)$ \\
\hline Singapore $2^{\text {nd }}$ subsample & $1.16(1.04,1.34)$ & 1.05 (0.81, 1.39) & $1.01(0.87,1.20)$ \\
\hline Thailand $1^{\text {st }}$ subsample & $0.84(0.13,1.19)$ & 1.14 (0.99, 1.35) & $1.53(1.23,1.90)$ \\
\hline Thailand $2^{\text {nd }}$ subsample & $1.01(0.88,1.20)$ & 1.31 (1.13, 1.58) & $1.19(1.04,1.37)$ \\
\hline Vietnam $1^{\text {st }}$ subsample & $1.09(0.93,1.35)$ & $0.91(0.84,0.99)^{*}$ & $1.05(0.95,1.19)$ \\
\hline Vietnam $2^{\text {nd }}$ subsample & $1.13(1.03,1.28)$ & 1.12 (0.92, 1.42) & 1.19 (1.03, 1.40) \\
\hline
\end{tabular}

*. Evidence of mean reversion; in bold the cases with significant differences between the two subsamples. 
Table 10: Estimates of $d$ for the two subsamples using Gil-Alana (2008) and autocorr. $u t$

\begin{tabular}{|c|c|c|c|}
\hline & Vis-a-vis Reg. & Vis-a-vis USD & Vis-a-vis RMB \\
\hline Brunei $1^{\text {st }}$ subsample & $0.91 \quad(0.70,1.18)$ & $0.82(0.02,1.44)$ & $0.44 \quad(-0.14,1.06)$ \\
\hline Brunei $2^{\text {nd }}$ subsample & $0.73(0.45,1.17)$ & $0.85(0.75,0.99) *$ & $0.68(0.57,0.82)^{*}$ \\
\hline Cambodia $1^{\text {st }}$ subsample & $-0.13 \quad(-1.07,1.47)$ & $1.11(0.95,1.34)$ & $0.49 \quad(-0.03,1.27)$ \\
\hline Cambodia $2^{\text {nd }}$ subsample & $0.74(0.64,0.88)^{*}$ & $0.81 \quad(0.64,1.10)$ & $0.51(0.37,0.73)^{*}$ \\
\hline Indonesia $1^{\text {st }}$ subsample & $0.71 \quad(0.48,1.03)$ & $0.69(0.52,0.95)^{*}$ & $0.68(0.47,0.98)^{*}$ \\
\hline Indonesia $2^{\text {nd }}$ subsample & $0.73(0.56,0.96)^{*}$ & $0.77 \quad(0.60,1.03)$ & $0.84 \quad(0.67,1.07)$ \\
\hline Laos $1^{\text {st }}$ subsample & $0.28(0.15,0.46)^{*}$ & $0.82(0.65,1.11)$ & $0.82(0.61,1.16)$ \\
\hline Laos $2^{\text {nd }}$ subsample & $0.79(0.57,1.18)$ & $0.94 \quad(0.73,1.48)$ & $0.69(0.53,1.19)$ \\
\hline Malaysia $1^{\text {st }}$ subsample & $0.58(0.39,0.87)^{*}$ & $0.98 \quad(-0.26,1.71)$ & $0.64 \quad(-0.87,1.47)$ \\
\hline Malaysia $2^{\text {nd }}$ subsample & $0.49(0.38,0.67)^{*}$ & $0.73(0.64,0.87)^{*}$ & $0.76(0.65,0.88)^{*}$ \\
\hline Philippines $1^{\text {st }}$ subsample & $0.67(0.49,0.97)^{*}$ & $0.97 \quad(0.83,1.16)$ & $0.81 \quad(-0.89,1-34)$ \\
\hline Philippines $2^{\text {nd }}$ subsample & $1.01(0.84,1.24)$ & $0.78(0.63,0.98)^{*}$ & $0.81(0.65,0.97)^{*}$ \\
\hline Singapore $1^{\text {st }}$ subsample & $0.02(-0.76,1.33)$ & $0.95 \quad(0.85,1.10)$ & $0.33(-0.17,1.04)$ \\
\hline Singapore $2^{\text {nd }}$ subsample & $0.87(0.75,0.99)^{*}$ & $0.50(0.22,0.91)^{*}$ & $0.49(0.33,0.75)^{*}$ \\
\hline Thailand $1^{\text {st }}$ subsample & $-0.51(-1.16,0.46)^{*}$ & $0.78(0.64,0.99)^{*}$ & $1.06(-0.72,2.14)$ \\
\hline Thailand $2^{\text {nd }}$ subsample & $0.70(0.58,0.84)^{*}$ & $0.89 \quad(0.68,1.23)$ & $0.83(0.65,1.04)$ \\
\hline Vietnam $1^{\text {st }}$ subsample & $-0.17(-0.74,0.56) *$ & 1.04 (0.92, 1.19) & $0.93(0.74,1.11)$ \\
\hline Vietnam $2^{\text {nd }}$ subsample & $0.89 \quad(0.79,1.04)$ & 0.69 (0.43, 1.13) & 1.02 (0.81, 1.40) \\
\hline
\end{tabular}

*. Evidence of mean reversion; in bold the cases with significant differences between the two subsamples. 